\title{
Long-Term Respiratory and Genotoxic Effects in The Prestige Oil Spill
}

\author{
Gema Rodriguez-Trigo', MD, Jan-Paul Zock ${ }^{2,3,4}, \mathrm{PhD}$ and Joan A. Barberà ${ }^{5,6}, \mathrm{MD}$
}

${ }^{1}$ Servicio de Neumología, Hospital Clínico San Carlos, Universidad Complutense, Madrid, Spain; ${ }^{2}$ Institute of Global Health (IS Global), Barcelona, Spain;

${ }^{3}$ Universitat Pompeu Fabra (UPF), Barcelona, Spain; ${ }^{4}$ CIBER Epidemiología y Salud Pública (CIBERESP), Madrid, Spain; ${ }^{4}$ Department of Pulmonary

Medicine, Hospital Clinic-IDIBAPS, Barcelona, Spain, ${ }^{5}$ Biomedical Research Networking Center on Respiratory Diseases (CIBERES), Madrid, Spain.

\section{ABSTRACT}

In 2002, the wreckage of the Prestige tanker and the subsequent oil spill prompted an epidemiological study promoted by the Spanish Thoracic Society (SEPAR). The study evaluated the long-term health effects of oil exposure among fishermen who participated in clean-up activities. The study resulted in eight original articles addressing the long-term respiratory and genotoxic effects of the exposure to the spill. After the Prestige accident, three additional major oil spills have occurred. In all of them, epidemiological studies addressed effects of oil exposure on different aspects of human health and prompted the international collaboration in investigations on health consequences of oil exposure, being the effects on the respiratory tract one of the most consistently substantiated. In the present review we analyse the potential effects on human health of oil compounds and summarise the main findings of the investigations conducted in the Prestige oil spill and subsequent accidents. (BRN Rev. 2019;5(1):62-70)

Corresponding author: Joan Albert Barberà, jbarbera@clinic.ub.es

Key words: Chromosome aberrations. Disasters. Environmental pollutants. Fuel oils. Occupational exposure. Respiratory tract diseases. 
The Prestige oil spill occurred in November 2002 and settled a before and after in the investigations on the health effects related to this kind of disasters. Until then, research was scarce, mostly focused on the acute or short-term effects, limited to reported symptoms, not substantiated by objective functional or biological assessments, and it suffered from a number of methodological limitations. Assessment of exposure to oil compounds was overall limited and not quantitative, and only few studies performed semiquantitative assessments. The majority of studies reported an association between acute exposure to the spill and the presence of neurovegetative symptoms and irritation of the skin, eyes and throat. Pulmonary function has seldomly been evaluated ${ }^{1}$.

In this review we will describe the accident of the Prestige and the characteristics of the oil it contained, as well as the possible health consequences based on predicted data of exposure to the spill. Then we will review the studies carried out in this spill and in the subsequent spills that aimed to investigate long-term respiratory and genotoxic health effects. For readers interested in an exhaustive review of all the research conducted in relation to these oil spills, regardless of their objectives, we recommend the one by Laffon et al., published in $2016^{2}$.

\section{THE PRESTIGE ACCIDENT}

On November 13th, 2002 the 30-year-old single-hull oil tanker Prestige sent out a Mayday signal from a position close to Finisterre Cape on the Atlantic coast of Spain. The tanker was transporting bunker oil from Saint Petersburg in Russia and Ventspils in Latvia to Singapore

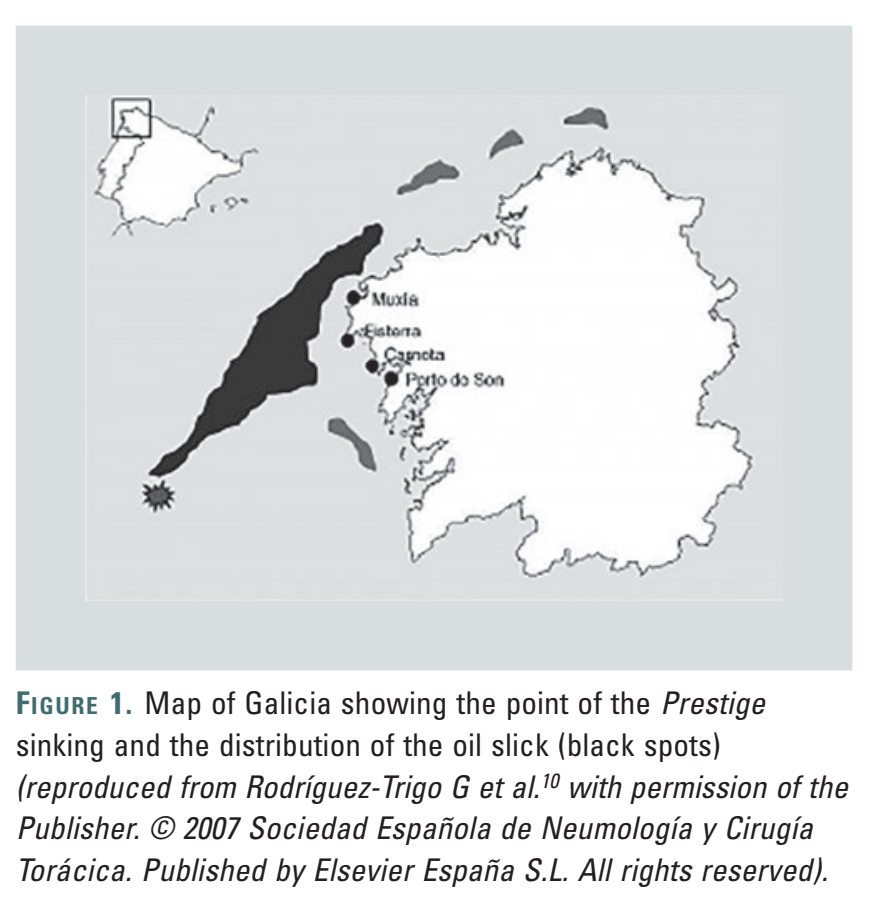

under a Bahamas flag of convenience. The first signs of the spillage were observed off the coast of Galicia (a region in the Northwest of Spain) on November 16th. After sinking 130 miles to the Southwest of Finisterre Cape on November 19th, the tanker discharged the larger part of its 77,000-ton cargo of bunker oil. The resulting oil slick affected the whole coastline of Galicia and part of Asturias and Cantabria, contiguous regions. Overall, about $300 \mathrm{~km}$ of coastline were affected. In the worst ecological disaster ever to affect Spain, the oil contaminated beaches, rocky shorelines, and the seabed. In Galicia, the spillage affected a considerable stretch of coastline in an irregular way determined by the particular geography of the seaboard, the weather conditions, and the marine currents (Fig. 1).

Cleaning up the spilled oil was a laborious and predominantly manual task and much of the work was carried out by teams of volunteers (made up of local residents from the 
Table 1. Composition of the Prestige fuel and theoretical toxicity of its components

\begin{tabular}{|c|c|c|}
\hline & Composition & Toxicity \\
\hline \multirow[t]{3}{*}{ Aromatic hydrocarbons $(50 \%)$} & Volatile organic compounds: benzene, toluene, xylene. & $\begin{array}{l}\text { Acute symptoms (respiratory } \\
\text { and neurovegetative). Carcinogens. }\end{array}$ \\
\hline & $\begin{array}{l}\text { Polycyclic aromatic hydrocarbons: naphthalene, } \\
\text { phenanthrene, dibenzothiophene, fluoranthene, } \\
\text { chrysene, and alkyl derivatives. }\end{array}$ & $\begin{array}{l}\text { Possible carcinogens. Endocrine alterations. } \\
\text { Skin and mucosal irritants }\end{array}$ \\
\hline & $\begin{array}{l}\text { High molecular weight: benzofluoranthenes, perilene, } \\
\text { benz[a]anthracene, benzo[a]pyrene, etc. }\end{array}$ & Probable carcinogens. Mucosal irritants. \\
\hline \multicolumn{3}{|l|}{ Saturated hydrocarbons $(22 \%)$} \\
\hline \multicolumn{3}{|l|}{ Resins and asphaltenes (28\%) } \\
\hline $\begin{array}{l}\text { Heteromolecules with atoms of sulphur, } \\
\text { oxygen, nitrogen, heavy metals } \\
\text { (cadmium, lead, nickel) }\end{array}$ & & Endocrine alterations. Carcinogens. \\
\hline
\end{tabular}

affected area but also of people who travelled from other parts of Galicia, other regions in Spain and other countries) in one of the most impressive displays of community support in our recent history. The impact on local communities was very significant because most of the crews of the fleet that usually fishes in Galician territorial waters (approximately 28,000 people) could not fish and had to spend every day for months -in some cases over a year- working on clean-up activities.

\section{TOXIC EFFECTS OF OIL SPILLS}

Oil is an organic mixture that is extracted from the earth's crust and transported to different parts of the world in pipelines and tanker ships. The unrefined product is called crude oil. In the refinery, crude oil is separated into light fractions (refinery gas and gasoline), intermediate fractions (kerosene and diesel), and heavy fractions (light fuel oil, heavy fuel oil and asphalt). The Prestige tanker was transporting a heavy fuel oil classified - because of its high sulphur content $(4 \%)$ - as
M100 in the Russian system, number 6 in English terminology, and number 2 on the French scale. This type of fuel is characterised by its high density $\left(992.1 \mathrm{~kg} / \mathrm{m}^{3}\right.$ at $\left.15^{\circ} \mathrm{C}\right)$ and strong viscosity (615 centistokes at $50^{\circ} \mathrm{C}$ and 30,000 at $15^{\circ} \mathrm{C}$ ). It has a low evaporation rate and natural dispersion and it forms a stable emulsion when mixed with water. The biodegradation rate of the spill is unknown and was probably under $10 \%$ in the first few months. The spilled fuel oil was composed of a complex mix of hydrocarbons, resins, asphaltenes, and heteromolecules (Table 1) 1,4. $^{3,4}$.

People involved in the task of cleaning up the oil were exposed to these potentially toxic substances, which mainly enter the human organism either by inhalation or through the skin and mucous membranes. The digestive tract is another route, although less important, that should be taken into account. The subsequent kinetics of these substances is poorly understood. Animal studies show that hydrocarbons accumulate primarily in the lungs and in organs with a 
high fat content. Since the detoxification process generates metabolites and conjugates that are eliminated in urine and faeces, they do not, in general, remain in the organism. The metabolic process may also generate reactive molecules that bind to DNA to form adducts.

Acute exposure to volatile organic compounds (VOCs) may cause neurological symptoms, such as headache, nausea, dizziness, and sleepiness. It can also cause breathlessness, vomiting and abdominal pain ${ }^{5,6}$. The classification published by the International Agency for Research on Cancer (IARC) ${ }^{7}$ categorises some of the VOCs present in the oil being transported by the Prestige (mainly benzene) as Group 1 agents, that is, substances that have been evaluated as being proven human carcinogens. Substances in this group are closely associated with hematologic cancer. Others, such as toluene, ethylbenzene and styrene, belong to Group 2B, the classification applied to agents that have been evaluated as being possibly carcinogenic to humans on the basis of evidence of carcinogenicity in animals. Polycyclic aromatic hydrocarbons can damage skin and mucous membranes, and are toxic to the endocrine system ${ }^{8}$. These compounds have been implicated in the pathogenesis of tumours, and especially in the formation of skin tumours. The following polycyclic aromatic hydrocarbons present in the fuel oil carried by the Prestige are classified by the IARC as Group 2A agents and are, therefore, considered probably carcinogenic to humans: benz[a]anthracene, benzo[a] pyrene and dibenz[a,h]anthracene. Others, such as naphthalene, benzo[b]fluoranthene, benzo[j]fluoranthene and benzo[k]fluoranthene, are classified as Group 2B substances, possibly carcinogenic to humans. Heavy metals also have carcinogenic properties and may affect the endocrine system. No research has been carried out to date on the long-term effects of exposure to this combination of toxic substances, the possibility of interactions between these agents, or the greater or lesser degree of individual susceptibility depending on the genetic profile.

\section{THE SEPAR-PRESTIGE STUDY}

The board of the SEPAR set up a multicentre, multidisciplinary research team in December 2002 to investigate the impact of the Prestige oil spill on human health. The SEPAR-Prestige Study being carried out by this team was an epidemiological survey of the clinical, biological and functional effects of the Prestige oil spill on the respiratory health of fishermen from the Galician coast. The study was the first one to analyse the long-term impact of exposure to oil spillage on respiratory health. Since people living in the affected coastal zone usually work in marine-related activities, the study population comprised 10,000 inshore fishermen and shellfish harvesters. The initial study had a cross-sectional design comprising two consecutive phases. In the first phase, the target population was defined using a questionnaire. In the second phase, two groups were studied (a group of exposed subjects and a group of unexposed controls). Participants completed a symptom questionnaire and underwent pulmonary function testing (forced spirometry and a methacholine challenge test). Sensitivity was assessed using biomarkers of oxidative stress and cytokines in exhaled breath condensate and serum immunoglobulin E. Chromosomal 


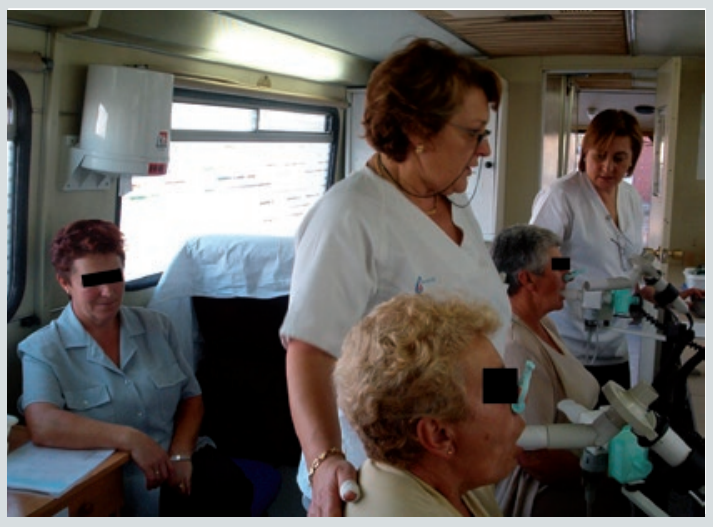

Figure 2. Pulmonary function studies in a mobile laboratory at the villages of fishermen participating in the study.

instability was studied using both conventional cytogenetic techniques and molecular analyses (Fig. 2).

A follow-up study was conducted 5-6 years after the spill in non-smoking exposed and unexposed fishermen who participated in the initial study to investigate the persistence ofrespiratory and genotoxic effects.

\section{MAJOR FINDINGS \\ OF THE SEPAR-PRESTIGE STUDY}

Fishermen who participated in the clean-up activities of the oil spilled by the Prestige tanker showed an increased prevalence of respiratory symptoms more than a year after the start of the spill, as shown in the first phase questionnaire9. This association was related to several types of cleaning activities and was consistent in different subgroups. The risk of presenting symptoms increased with the duration of cleaning activities and with the number of tasks performed and decreased as the time elapsed from the cessation of cleaning.

A more detailed assessment conducted in fishermen two years after the spill, comparing them according to the exposure to the spill ${ }^{10}$ (second phase), showed that participants in clean-up activities had a higher prevalence of respiratory symptoms, increased levels of biomarkers of inflammation and remodelling in the exhaled breath condensate, and greater prevalence of chromosomal alterations in peripheral blood lymphocytes, as compared with those who had not participated in cleaning activities.

A more thorough cytogenetic analysis of chromosomal lesion locations revealed three chromosomal bands commonly involved in haematological cancer as those most affected by the acute oil exposure: 2q21, 3q27 and 5q3111. Deoxyribonucleic Acid repair errors were assessed in lymphocyte cultures with aphidicolin, and significantly higher dysfunction in DNA repair mechanisms, expressed as chromosomal damage, was detected in oil-exposed participants compared to non-exposed participants. Nuclear anomalies (micronucleus [MN], nucleoplasmic bridges, and nuclear buds) were similar in exposed and non-exposed individuals ${ }^{12}$.

Results of the longitudinal study conducted more than five years after the Prestige oil spill ${ }^{13}$ showed that fishermen who had participated in clean-up activities had an increased prevalence of upper and lower respiratory symptoms, and used more frequently inhaled or oral medication for respiratory conditions, as compared to fishermen who had not participated in any cleaning activity. This excess risk was more evident when respiratory 
TABLE 2. Summary of publications reporting the results of the SEPAR-Prestige Study

\begin{tabular}{|c|c|c|c|c|}
\hline Study & Design & Subjects & $\begin{array}{l}\text { Time elapsed } \\
\text { after exposure }\end{array}$ & Main findings \\
\hline Zock et al ${ }^{9}$. & Cross-sectional & 6780 & $1-2$ years & $\begin{array}{l}\text { Association between participation in clean-up work and prolonged } \\
\text { respiratory symptoms }\end{array}$ \\
\hline $\begin{array}{l}\text { Rodriguez-Trigo } \\
\text { et } \mathrm{al}^{10} \text {. }\end{array}$ & Cross-sectional & $\begin{array}{l}501 \mathrm{E} \\
177 \mathrm{NE}\end{array}$ & 2 years & $\begin{array}{l}\text { Association between participation in clean-up work and persistent } \\
\text { respiratory symptoms, markers of airway injury in breath condensate } \\
\text { and chromosomal damage }\end{array}$ \\
\hline Monyarch et al ${ }^{11}$. & Cross-sectional & $\begin{array}{c}91 \mathrm{E} \\
46 \mathrm{NE}\end{array}$ & 2 years & $\begin{array}{l}\text { Chromosome bands affected }(2 q 21,3 q 27,5 q 31) \text { and DNA repair } \\
\text { dysfunction in exposed individuals }\end{array}$ \\
\hline Biern et al ${ }^{12}$. & Cross-sectional & $\begin{array}{l}14 \mathrm{E} \\
14 \mathrm{NE}\end{array}$ & 2 years & No differences in nuclear abnormalities \\
\hline Zock et al ${ }^{13}$. & Longitudinal & $\begin{array}{l}466 \mathrm{E} \\
156 \mathrm{NE}\end{array}$ & 5 years & Respiratory symptoms persist in clean-up workers \\
\hline Zock et al ${ }^{14}$. & Longitudinal & $\begin{array}{l}230 \mathrm{E} \\
87 \mathrm{NE}\end{array}$ & 6 years & $\begin{array}{l}\text { No formally demonstrate persistence of respiratory health impairment } \\
\text { was due to exposure (methodological issues) }\end{array}$ \\
\hline Hildur et al ${ }^{15}$. & Longitudinal & $\begin{array}{l}52 \mathrm{E} \\
23 \mathrm{NE}\end{array}$ & 6 years & Chromosome damage persist in exposed and increase in nonexposed \\
\hline Francés et al ${ }^{16}$. & Longitudinal & $\begin{array}{l}47 \mathrm{E} \\
22 \mathrm{NE}\end{array}$ & 6 years & Chromosome bands affected in exposed: $2 p 23,2 q 23$ \\
\hline
\end{tabular}

E: exposed; NE: non-exposed.

symptoms were present both in the initial study and in the follow up, and increased according to the intensity of exposure to oil during the cleaning work.

There was no improvement in the pulmonary function and biological respiratory parameters after four years of follow-up in the fishermen exposed to fuel, although there was no clear data indicating that the degree of exposure was associated with the long-term effects ${ }^{14}$. A long-term genotoxic study, conducted in 52 exposed and 23 non-exposed individuals, showed that structural alterations remained high in exposed individuals, although the association with the exposure to the oil spill could not be substantiated because there was a relevant increase of structural alterations in nonexposed individuals ${ }^{15}$. Nevertheless, 2p23 and 2q23 chromosome bands were only detected in exposed individuals ${ }^{16}$ The main results of the SEPAR-Prestige Study are summarised in table 2.

\section{ADDITIONAL STUDIES ON THE PRESTIGE OIL SPILL}

The first investigations on acute genotoxicity related to the exposure to the oil of the Prestige tanker were carried out in subjects involved in autopsies and cleaning of oil-contaminated birds ${ }^{17}$ and in volunteers and hired workers participating in clean-up tasks ${ }^{18-22}$ using different parameters, which showed a significant increase in relation to the corresponding control group.

An in vivo study using a rat model of sub-chronic exposure to a fuel oil with characteristics 
TABLE 3. Prestige oil spill and subsequent accidents

\begin{tabular}{|l|c|c|c|c|}
\hline Oil spill & Size (tons) & Type & Site & Year \\
\hline Prestige & 67,000 & Fuel oil \# 6 & Galicia, Spain & 2002 \\
\hline Tasman Spirit & 37,000 & Crude oil & Karachi, Pakistan & 2003 \\
\hline Hebei Spirit & 10,900 & Crude oil & Taean, Korea & 2007 \\
\hline Deepwater Horizon & 680,000 & Crude oil & Gulf of Mexico, US & 2010 \\
\hline
\end{tabular}

similar to those of the oil spilled by the Prestige tanker was carried out by Valdiglesias et al. ${ }^{23}$, in order to determine the potential genotoxic effects under strictly controlled exposure conditions. Their results showed that oil exposure by inhalation induced DNA damage in rats, and alterations in DNA repair responses, although the sensitivity to oil substances varied depending on the rat strain. These data provide further support for the genotoxic effects shown in individuals exposed to the Prestige oil during cleanup tasks ${ }^{23}$. A follow-up study of genotoxic damage, carried out seven years after the Prestige accident, in individuals exposed to the oil for a mean of nine months, failed to show differences between exposed individuals and controls in the comet assay of DNA damage, the $\mathrm{T}$-cell receptor mutation assay, and the cytokinesis-block micronuclei test ${ }^{24}$, suggesting that bone-marrow hematopoietic stem cells do not necessarily display permanent damage in their DNA, as long as subjects remain free of exposure for a long period of time.

\section{STUDIES ON OIL SPILLS AFTER THE PRESTIGE ACCIDENT}

Three oil spills occurring after the Prestige accident in 2002 have deserved investigations on the effects on human health (Table 3). These investigations have focused on the acute effects, the repercussions on mental health and different measures of exposure. Two investigations deserve particular attention in the context of the present review.

Jung et al. ${ }^{25}$ evaluated the effects of the exposure to oil in children. These investigators conducted a cross-sectional study in 2013, 1.5 years after the Hebei Spirit accident (South Korea), to analyse the respiratory effects in 436 children who lived along the Yellow Coast. Children who lived close to the oil spill area showed a significantly lower forced expiratory volume in one second $\left(\mathrm{FEV}_{1}\right)$, an increased prevalence of asthma and airway hyperresponsiveness, as compared with children who lived far from the oil spill area. Male gender, family history of asthma and residence near the oil spill area were significant risk factors for asthma.

The most important oil spill was the one that occurred in the Gulf of Mexico in 2010, where 680,000 tons of crude oil were released from a wellhead after the explosion and sinking of the drilling platform Deepwater Horizon. Additionally, over 1.8 million gallons of chemical dispersants -Corexit 9500 and 9527A- were applied to the surface and subsurface environments. In relation to this spill, Rusieki et 
al. ${ }^{26}$ investigated long-term effects of oil exposure, using an approach similar to that in the SEPAR-Prestige Study. A cohort was established using administrative databases of over 50,000 US Coast Guard members on active duty or in the Selected Reserve, between the start of the oil spill on April $20^{\text {th }}, 2010$ and December $17^{\text {th }}, 2010$. For many of these military workers, health data from periodical medical contacts and health assessments were available. More than 8000 of them had participated in clean-up activities of the oil spill, and hence the large remaining group could be used as an appropriate control population. More than half of the Coast Guard members who participated in the clean-up work completed a questionnaire on exposure characteristics and self-reported health outcomes. Longitudinal analyses, 2 years after the exposure, revealed that exposure to the oil spill was associated with an increased risk for chronic respiratory conditions, asthma and dermal conditions ${ }^{26}$.

The investigation of the repercussions of oil spills on human health in the long term entails significant methodological difficulties. The studies conducted on the Prestige oil spill represented a step forward in this field and contributed to settle the methodological approach for subsequent studies. Lessons learned in the Prestige spill underscore the necessity to design broad population studies, with documented prior information on the health status of the population. It is important to have an adequate control group not exposed to fuel. Ideally, objective measures of exposure and its consequences are needed. In longitudinal studies, we must ensure the size of the control group to avoid bias.

\section{CONCLUSIONS}

Oil spills occur with certain frequency and cause serious consequences to ecosystems, economy and human health. Cleaning activities of the spills are undertaken by professionals or volunteers that may not be well prepared or protected. Since, regrettably, these disasters may occur again anywhere, we consider it essential to use adequate protection measures and actively monitor the health status of individuals exposed to the oil. From the point of view of research studies, the response should also be immediate and funded by public health authorities.

\section{ACKNOWLEDGEMENTS}

The authors of this concise review were members of the SEPAR-Prestige Study Group. Due to editorial constraints the number of authors of the review is limited to three. However, the study would not have been possible without the contribution of many people, including $\mathrm{F}$ Pozo, L Bouso, Y Torralba, JM Antó, FP Gómez, C Fuster, H Verea, G Monyarch, MD Coll, F Burgos, A Espinosa, L Vázquez, L Rodríguez-Valcárcel, A Souto, M Blanco, A Serrano-Mollar, O Bulbena, J Tò, J Egozcue, E Toubes, I Isidro, A Palacios, and M Suárez. We want to thank them for their collaboration and enthusiastic participation in the study. ISGlobal and IDIBAPS are members of the Centres de Recerca de Catalunya (CERCA) Programme, Generalitat de Catalunya.

\section{DISCLOSURES}

The authors have nothing to disclose. 


\section{REFERENCES}

1. Rodríguez-Trigo G, Zock JP, Isidro Montes I. Health effects of exposure to oil spills. Arch Bronconeumol. 2007;43:628-35.

2. Laffon B, Pásaro E, Valdiglesias E. Effects of exposure to oil spills on human health: Updated review. J Toxicol Environ Health. 2016;19: 105-28.

3. Consejo Superior de Investigaciones Científicas. Informe técnico CSIC "Prestige". Caracterización del vertido y evolución preliminar en el medio. Available from: http://csicprestige.iim.csic.es/desarro/informcsic/1/index.htm.

4. Centre de Documentation de Recherche et d'Expérimentations sur les pollutions accidentelles des eaux. June 2003. Accidents: Prestige. Available from: http://www.lecedre.fr/.

5. Consejo Superior de Investigaciones Científicas. Informe técnico CSIC "Prestige". Sobre la toxicidad de los residuos de petróleo del Prestige. Available from: http://csicprestige.iim.csic.es/desarro/informcsic/11/info11.htm.

6. Bosch X. Exposure to oil spill has detrimental effect on clean-up workers health. Lancet. 2003;361:147.

7. IARC. Overall evaluations of carcinogenicity-an updating of IARC monographs volumes 1 to 42. International Agency for Research on Cancer, Monographs on the Evaluation of Carcinogenic Risk to Humans, Suppl. 7. Lyon: IARC; 1987.

8. Agency for Toxic Substances and Disease Registry. US Toxicological Profile for Fuel-oils. June 1995. Department of Health and Human Services. Public Health Service. Available from: www.atsdr. cdc.gov/toxprofiles/tp75-c2.pdf.

9. Zock JP, Rodríguez-Trigo G, Pozo-Rodríguez P et al. Prolonged Respiratory Symptoms in Clean-up Workers of the Prestige Oil Spill. Am J Respir Crit Care Med. 2007;176:610-6.

10. Rodríguez-Trigo G, Zock JP, Pozo-Rodríguez F et al. Health Changes in Fishermen 2 Years After Clean-up of the Prestige Oil Spill. Ann Intern Med. 2010;153:489-98.

11. Monyarch G, de Castro Reis F, Zock JP et al. Chromosomal Bands Affected by Acute Oil Exposure and DNA Repair Errors. Chromosomal Bands Affected by Acute Oil Exposure and DNA Repair Errors. PLoS ONE. 2013;8:e81276.

12. Biern G, Giraldo J, Zock JP et al. 2015. Human genotoxic study carried out two years after oil exposure during the clean- up activities using two different biomarkers. J Mar Sci Eng. 2015;3:1334-48.

13. Zock JP, Rodríguez-Trigo G, Rodríguez-Rodríguez E et al. Persistent respiratory symptoms in clean-up workers 5 years after the Prestige oil spill. Occup Environ Med; 2012,69:508-13.
14. Zock JP, Rodríguez-Trigo G, Rodríguez-Rodríguez E et al. Evaluation of the persistence of functional and biological respiratory health effects in cleanup workers 6 years after the Prestige oil spill. Environ Int. 2014;62:72-7.

15. Hildur K, Templado C, Zock JP, Giraldo J et al. Follow-Up Genotoxic Study: Chromosome Damage Two and Six Years after Exposure to the Prestige Oil Spill. PLoS ONE. 2015;10:e0132413.

16. Francés A, Hildur K, Barberà JA et al. Persistence of Breakage in Specific Chromosome Bands 6 Years after Acute Exposure to Oil. PLoS ONE. 2016;11: e0159404.

17. Laffon B, Fraga-Iriso R, Pérez-Cadahía B, Méndez J. Genotoxicity associated to exposure to Prestige oil during autopsies and cleaning of oil-contaminated birds. Food Chem Toxicol. 2006;44:1714-23.

18. Pérez-Cadahía B, Laffon B, Pásaro E, Méndez J. Genetic damage induced by accidental environmental pollutants. Scientific World Journal. 2006;6: 1221-37.

19. Pérez-Cadahía B, Lafuente A, Cabaleiro T, Pásaro E, Méndez J, Laffon B. Initial study on the effects of Prestige oil on human health. Environ Int. 2007;33:176-85.

20. Pérez-Cadahía B, Méndez J, Pásaro E, Lafuente A, Cabaleiro T, Laffon B. Biomonitoring of human exposure to Prestige oil: Effects on DNA and endocrine parameters. Environ Health Insights. 2008;2:83-92.

21. Pérez-Cadahía B, Laffon B, Valdiglesias V, Pásaro E, Méndez J. Cytogenetic effects induced by Prestige oil on human populations: The role of polymorphisms in genes involved in metabolism and DNA repair. Mutat Res. 2008;653:117-23.

22. Pérez-Cadahía B, Laffon B, Porta M et al. Relationship between blood concentrations of heavy metals and cytogenetic and endocrine parameters among subjects involved in cleaning coastal areas affected by the 'Prestige' tanker oil spill. Chemosphere. 2008;71:447-55.

23. Valdiglesias V, Kiliç G, Amor-Carro O et al. In vivo genotoxicity assessment in rats exposed to Prestige-like oil by inhalation. J Toxicol Environ Health A. 2012;75:756-64.

24. Laffon B, Aguilera F, Ríos-Vázquez J, Valdiglesias V, Pásaro E. Follow-up study of genotoxic effects in individuals exposed to oil from the tanker Prestige, seven years after the accident. Mutat Res. 2014;760:10-16.

25. Jung SC, Kim KM, Lee KS et al. Respiratory effects of the Hebei Spirit oil spill on children in Taean, Korea. Allergy, Asthma Immun Res. 2013;5: 365-70.

26. Rusiecki J, Alexander M, Schwartz EG et al. The Deepwater Horizon Oil Spill Coast Guard Cohort study. Occup Environ Med. 2018;75:165-75. 